\title{
EVALUASI FAKTOR MANFAAT SISTEM LINGKUNGAN PEMBELAJARAN 3 DIMENSI BERBASIS MULTI-USER VIRTUAL REALITY (MUVR)
}

\author{
Adhi Rizal*1, Dadang Yusup ${ }^{2}$, Apriade Voutama ${ }^{3}$ \\ ${ }^{1,2,3}$ Universitas Singaperbangsa Karawang \\ Email: 1adhi.rizal@staff.unsika.ac.id, ${ }^{2}$ dadang.dyf@staff.unsika.ac.id, ${ }^{3}$ apriade.voutama@staff.unsika.ac.id \\ *Penulis Korespondensi
}

(Naskah masuk: 15 Juli 2019, diterima untuk diterbitkan: 05 Oktober 2020)

\begin{abstract}
Abstrak
Faktor manfaat (usability) suatu teknologi dalam pembelajaran merupakan salah satu isu yang paling menonjol dalam bidang pendidikan. Salah satu teknologi pembelajaran yang sedang berkembang saat ini adalah sistem lingkungan pembelajaran 3 dimensi berbasis Multi-user Virtual Reality (MuVR). MuVR merupakan perpaduan antara teknologi Virtual Reality (VR) dengan dunia virtual 3 dimensi di dalamnya. Suatu teknologi pembelajaran dapat dikatakan berhasil diterapkan ketika aspek faktor manfaat yang merupakan kunci keberhasilan dapat tercapai. Berdasarkan hal ini, maka penelitian ini berupaya untuk melakukan evaluasi faktor manfaat terhadap sistem pembelajaran yang yang telah dikembangkan, yaitu 3D-MuVLR (3-Dimensional Multi-user Virtual Learning Reality). Sistem ini merupakan sistem pembelajaran yang memanfaatkan teknologi VR dengan jenis semi-immersive. Metode evaluasi faktor manfaat yang digunakan dalam penelitian ini mengadopsi 12 prinsip heuristik yang diusulkan oleh Sutcliffe. Evaluasi heuristik ini merupakan perpaduan antara aspek faktor manfaat dan keberadaan pengguna di dalam lingkungan virtual. Proses evaluasi dilakukan oleh tiga evaluator. Hasil evaluasi menunjukan bahwa secara keseluruhan 3D-MuVLR dapat merepresentasikan lingkungan pembelajaran dengan baik. Walaupun demikian terdapat beberapa permasalahan aspek desain terkait dengan minimnya petunjuk atau informasi di dalam sistem mengenai prosedur untuk masuk atau keluar sistem dan informasi mengenai cara melaksanakan kegiatan pembelajaran. Selain itu ketika proses evaluasi dilaksanakan, ditemukan juga gejala cybersickness yang dialami oleh evaluator. Namun durasi penggunaan sistem yang menyebabkan cybersickness berbeda-beda untuk setiap pengguna. Walaupun demikian durasi penggunaan sistem kurang dari sepuluh menit, evaluator sudah mulai merasakan gejala cybersickness, seperti pusing. Berdasarkan hal ini faktor yang dapat mempengaruhi munculnya gejala cybersickness adalah gerakan atau posisi kepala pengguna dan spesifikasi perangkat keras yang digunakan.
\end{abstract}

Kata kunci: MuVR, VR, 3D-MuVLR, evaluasi, faktor manfaat, cybersickness

\section{USABILITY EVALUATION OF A 3 DIMENSIONAL LEARNING ENVIRONMENT SYSTEM BASED ON MULTI-USER VIRTUAL REALITY (MUVR)}

\begin{abstract}
Usability in learning technology is one of the most prominent issues in education. One of the emerging learning technologies is the 3-dimensional learning environment system based on Multi-user Virtual Reality (MuVR). It is a combination of VR with a 3-dimensional virtual world. The successful of learning technology implementation is when its usability can be achieved. Therefore, this study aims to evaluate the usability of learning system that we have developed, which is 3D-MuVLR (3-Dimensional Multi-user Virtual Learning Reality). Furthermore, it is a learning system that utilizes semi-immersive VR. We adopted a usability evalution method consisiting of 12 heuristic rules proposed by Sutcliffe. It is a combination of usability and user's sense of presence in the virtual world. The evaluation process involved three evaluators. The results showed that $3 D-M u V L R$ can represent the learning environment as in a real world. However, there were several design aspect problems identified related to the lack of instructions of information in the system regarding procedures on how to enter or quit system and the absence of information on how to participate in learning activities. In addition, when the evalution process was carried out, we also found that the symptoms of cybersicness was experienced by evaluators. But the duration while they were using the system until they starts to feel sick varies for every user. Overall, although the duration of using the system was less than ten minutes, evaluators began to feel the symptoms of cybercickness, such as dizzines. Based on this, we found that the head position or movement and hardware specification are factors that cause this.
\end{abstract}

Keywords: $M u V R, V R, 3 D-M u V L R$, evaluation, usability, cybersickness 


\section{PENDAHULUAN}

Kaitan yang erat antara perkembangan teknologi dan dunia pendidikan di abad ke-21 ini berhasil menciptakan inovasi berupa e-learning (Torun \& Tekedere, 2015). Salah satu teknologi yang dapat diterapkan pada pelaksanaan pembelajaran berbassis e-learning adalah Virtual Reality (VR) yang dilengkapi dengan dunia digital di dalamnya sehingga dikenal virtual learning environment (VLE). VLE merupakan tempat pengguna berinteraksi baik dengan sesama pengguna maupun dengan objekobjek virtual lain yang ada di dalamnya (Achiruzaman \& Rosmansyah, 2016), (Simonics, 2013), (Ewais \& De Troyer, 2014).

VR didefinisikan sebagai simulasi interaktif dari suatu ruang 3 dimensi yang memiliki karakteristik multisensor, immersive, dan real-time yang dapat dirasakan oleh pengguna melalui perangkat input dan output 3 dimensi (Ewais \& De Troyer, 2013). Pada umumnya pemanfaatan teknologi VR ini semakin banyak digunakan di seluruh dunia melalui perangkat ponsel pintar (smartphone) (Martín-Gutiérrez, et al., 2017). Selain karakteristik dan fiturnya yang unik, teknologi VR juga dianggap mudah digunakan oleh berbagai kalangan pengguna (Martín-Gutiérrez, et al., 2017). Berdasarkan hal tersebut, maka perkembangan teknologi VR banyak dimanfaatkan untuk berbagai aspek kehidupan (Yildirim, et al., 2018), termasuk pada bidang pendidikan (Çavaş, et al., 2004), (Abulrub \& Williams, 2011), (Moore, 1995), (Ewais \& De Troyer, 2014), (Yildirim, et al., 2018).

Teknologi VR dapat mendukung proses pembelajaran berupa inovasi jenis atau gaya belajar yang lebih baik serta kemudahan dalam proses belajar mengajar (Cartelli, 2009). Ketika VR diimplementasikan pada proses pembelajaran, dunia yang terdapat di dalamnya biasa disebut dengan VLE dalam bentuk 3 dimensi (3D-VLE). 3D-VLE merupakan salah satu jenis e-learning yang mengintegrasikan teknologi informasi dan komunikasi dalam proses pembelajaran (Rizal, et al., 2018), (Simonics, 2013). Sistem 3D-VLE juga merupakan platform yang dapat dikembangkan berdasarkan imajinasi dari penggunanya (Reisoğlu, et al., 2017) dan pada umumnya dikenal juga sebagai course management system yang dapat divisualisasikan dalam bentuk lingkungan 3 dimensi, serta banyak digunakan pada proses pembelajaran pembelajaran (Livingstone \& Kemp, 2008), (Chau, et al., 2013), (Ak \& Kutlu, 2015) untuk meningkatkan keterlibatan dan pengalaman belajar peserta didik (Domingo \& Badley, 2018), (Karaman \& Özen, 2016).

Saat ini perpaduan antara VR dengan VLE di dalamnya memicu inovasi baru di dalam penerapan keduanya secara bersamaan, yaitu Multi-User Virtual Reality (MuVR). MuVR merupakan suatu konsep interaksi antara pengguna di dalam dunia virtual yang dilengkapi dengan fungsi untuk berkomunikasi secara real-time dengan pengguna VR lainnya (Zhao, 2018). Dengan adanya MuVR diharapkan memicu munculnya paradigma baru pada metode dan model pembelajaran yang digunakan sehingga proses pembelajaran menjadi lebih aktif dan berpusat pada peserta didik (Velev \& Zlateva, 2017).

Walaupun teknologi MuVR memiliki banyak keunggulan, namun kekayaan dari fitur dan manfaatnya juga dapat menjadi kelemahannya. Pengguna pemula biasanya akan kesulitan menemukan jalan atau petunjuk atau bahkan tersesat di lingkungan virtual dan mengalami kesulitan untuk melakukan navigasi dan berinteraksi dengan objekobjek di lingkungan 3 dimensi. Di sisi lain, pengguna yang sudah terbiasa dapat menghabiskan waktunya dengan melakukan eksplorasi secara berlebihan dan mencoba untuk berinteraksi dengan semua fitur dan objek yang ada di VLE, sehingga kehilangan fokusnya terhadap kegiatan pembelajaran (Rizal, et al., 2018), (Ewais \& De Troyer, 2013).

Berdasarkan penelitian yang dilakukan oleh (De Bra, et al., 2010) menyatakan bahwa VLE di dalam MuVR harus dapat beradaptasi dengan pilihan personal, pengetahuan, dan kemampuan atau kompetensi peserta didik, tujuan pembelajaran, serta konteks kultur atau sosial tempat kegiatan pembelajaran tersebut berlangsung. Lebih dari itu, adaptabilitas dan faktor manfaat (usability) dalam dunia virtual dapat menyebabkan proses pembelajaran menjadi lebih atraktif dan memotivasi peserta didik.

Berdasarkan permasalahan yang telah dipaparkan, kualitas dan faktor manfaat merupakan kunci keberhasilan penerapan VLE karena dapat mempengaruhi kepuasan dan penerimaan pengguna (Vertesi, et al., 2018). Jika suatu sistem memiliki tingkat faktor manfaat yang rendah, maka akan menghabat efektifitas dan efisiensi penggunaan sistem tersebut (Barnum, 2002). Oleh karena itu, proses evaluasi faktor manfaat dari desain aplikasi dan menginvestigasi permasalahan yang mungkin terjadi ketika proses implementasi merupakan hal yang penting untuk dilakukan (Dix, et al., 2004).

Salah satu cara untuk melakukan evaluasi terhadap aspek faktor manfaat adalah dengan menggunakan metode evaluasi heuristik. Evaluasi Heuristik merupakan salah satu metode untuk melakukan inspeksi dan merupakan salah satu bentuk pengujian faktor manfaat antarmuka aplikasi yang memiliki prinsip role of thumbs (Paulus, et al., 2016). Terdapat beberapa metode untuk melakukan evaluasi heuristik, namun metode yang dikembangkan oleh (Sutcliffe \& Gault, 2004) secara khusus digunakan untuk aplikasi VR dengan melibatkan aspek faktor manfaat. Namun, teknologi VR yang saat ini banyak digunakan adalah Google Cardboard, VR Box, ANTVR kit, dan Samsung Gear VR yang merupakan teknologi VR dengan jenis semi-immersive (Paulus, et al., 2016). Hal ini disebabkan karena proses 
instalasi atau penggunaan yang mudah, sederhana, dan harga yang lebih terjangkau namun tidak mengurangi pengalaman yang dirasakan oleh pengguna.

Berbeda dengan beberapa penelitian sebelumnya yang melakukan evaluasi secara umum terhadap sistem VR tanpa adanya avatar, penelitian ini bertujuan untuk melakukan evaluasi faktor manfaat heuristik terhadap sistem MuVR dengan jenis semi-immersive dengan mengadopsi 12 aturan heuristik yang diusulkan oleh Sutcliffe. Secara spesifik sistem yang digunakan selama proses evaluasi adalah sistem kelas virtual yang digunakan untuk melakukan proses pembelajaran lengkap dengan objek pembelajaran dan avatar untuk merepresentasikan pengguna. Selain itu pada penelitian ini juga akan dipaparkan mengenai kemungkinan terjadinya Cybersickness (Davis, et al., 2015) (LaViola Jr, 2000) berdasarkan penggunaan $V R$ Box selama proses evaluasi.

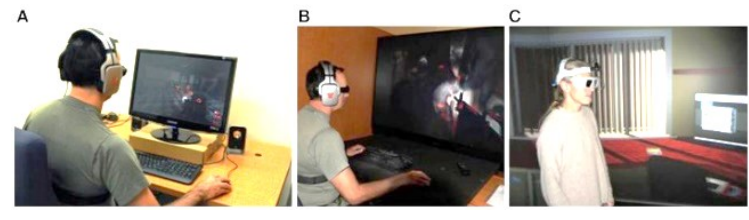

Gambar 1. Jenis VR: (A) non-immersive; (B) semiimmersive; (C) immersive

\section{METODE PENELITIAN}

Objek penelitian dalam studi kasus ini adalah evaluasi faktor manfaat terhadap sistem bebasis VR. Konsep penerapan VR sendiri saat ini dibagi menjadi 3 yaitu non-immersive, semi-immersive, dan immersive seperti yang ditunjukan pada

Gambar 1 (Baus \& Bouchard, 2014), (Mathew, 2014), (Ramaprabha \& Sathik, 2012).

Walaupun demikian, proses evaluasi faktor manfaat dilakukan terhadap sistem pembelajaran berbasis 3D yang divisualisasikan dengan konsep semi-immersive $V R$ yang disebut dengan 3D-Multi user Virtual Learning Reality (3D-MuVLR). Arsitektur 3D-MuVLR secara umum dan tampilan sistem di dalam smartphone dan masing-masing ditunjukan pada Gambar 2 dan Gambar 4.

Konsep semi-immersive $V R$ terdiri dari sistem komputasi grafis dengan performa tinggi yang divisualisasikan dengan layar dengan ukuran besar dan memiliki resolusi tinggi. Namun sebagai alternatif untuk penggunaan layar dengan ukuran besar, teknologi ini juga dapat diimplementasikan menggunakan perangkat headset yang terdiri dari dua lensa likuid masing-masing yang ditempatkan di depan mata pengguna (Costello, 1997). Dalam penelitian ini evaluator sistem adalah para ahli dan berpengalaman dalam penerapan teknologi untuk pembelajaran. Secara keseluruhan, tahapan penelitian ini dapat dilihat pada Gambar 3.
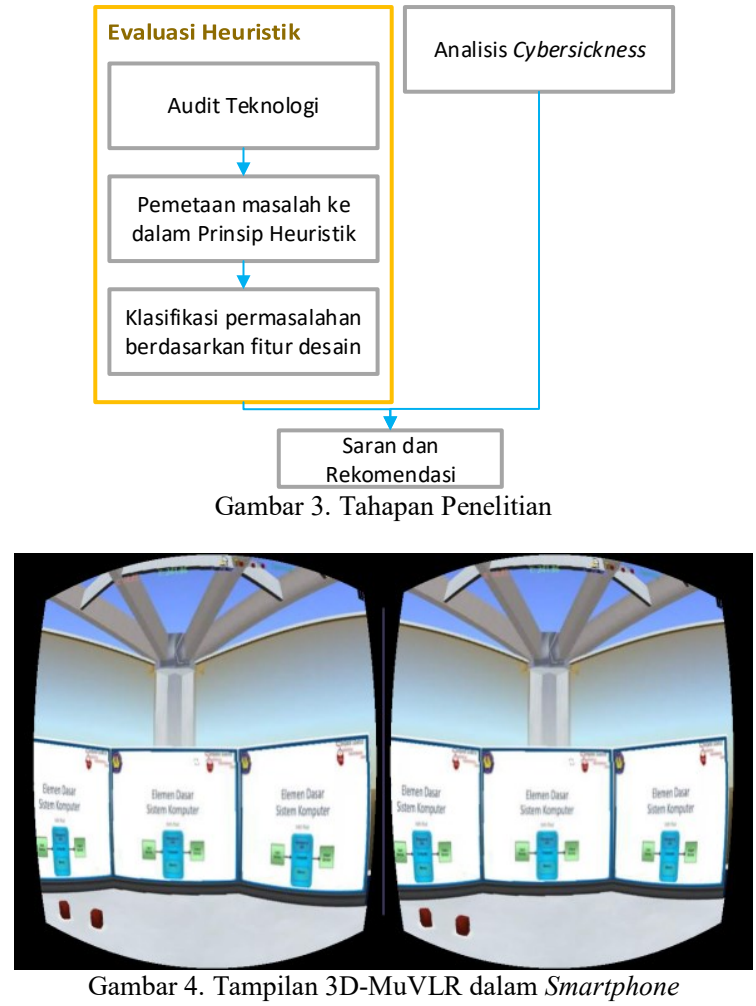

2.1 Evaluasi Heuristik

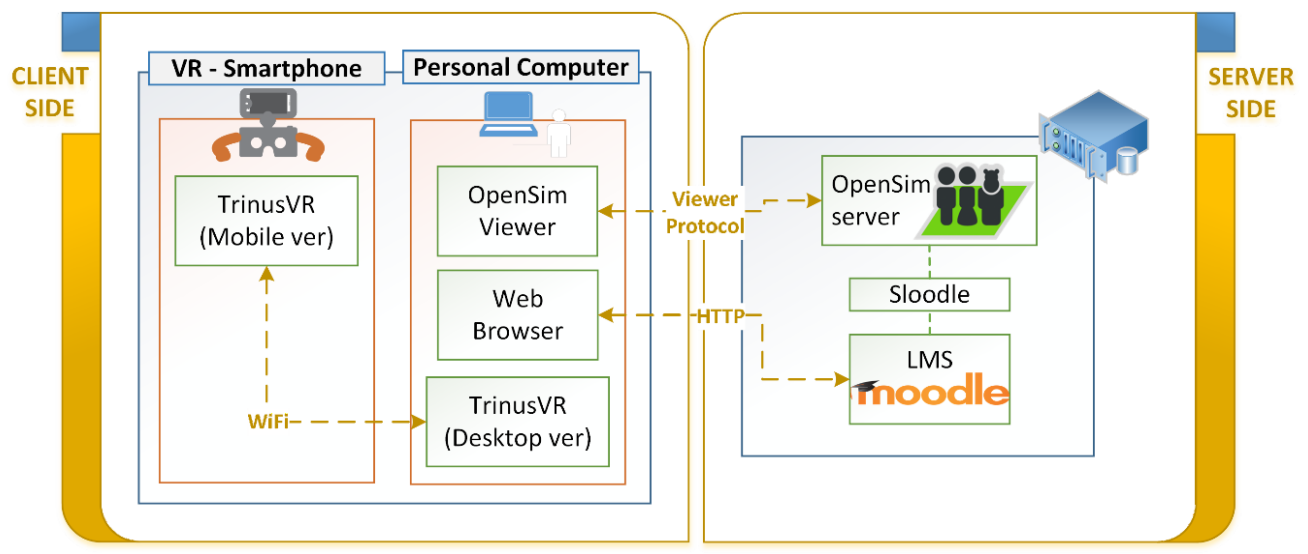

Gambar 2. Arsitektur 3D-MuVLR 
Evaluasi heuristik merupakan metode untuk menginvestigasi faktor manfaat suatu sistem yang mencakup proses peninjauan dan penilaian desain antarmuka pengguna (Sutcliffe \& Gault, 2004). Metode investigasi ini dapat dilakukan menggunakan panduan berupa daftar aktivitas yang harus dilakukan sebagai kriteria untuk menelaah permasalahan faktor manfaat. Metode evaluasi yang dikembangkan berdasarkan (Nielsen, 1993) ini bertujuan untuk mencari kekurangan dari desain antarmuka yang ada pada suatu sistem atau perangkat lunak. Dibandingkan dengan metode evaluasi lain, metode evaluasi heuristik dapat dilakukan dengan cepat karena hanya dilakukan oleh beberapa evaluator (3 sampai 5 evaluator) yang merupakan pakar di bidangnya (Nielsen, 1993).

Evaluasi heuristik digunakan atar dasar kebutuhan untuk menganalisis seberapa besar tingkat interaksi dan immersive suatu aplikasi VR dan dengan tujuan untuk menyimulasikan dunia nyata serealistis mungkin berdasarkan 12 prinsip (Sutcliffe \& Gault, 2004), yaitu sebagai berikut:

1) Natural engagement. Interaksi atau keterlibatan di dalam dunia virtual harus sesuai dengan harapan pengguna. Dengan kata lain pengguna hampir tidak menyadari bahwa dirinya sedang berada di dunia virtual.

2) Compatibility with the user's task and domain. Dunia virtual dan perilaku objek yang berada di dalamnya mirip dengan aslinya sehingga sesuai dengan harapan pengguna.

3) Natural exprression of action. Representasi pengguna dalam dunia virtual harus dapat bergerak secara bebas tanpa batasan fisik. Pengguna dapat melakukan eksplorasi secara bebas di dalam dunia virtual.

4) Close coordination of action and representation. Pergerakan yang dilakukan dengan dunia virtual harus dilakukan tanpa adanya "lag" atau jeda waktu yang menyebabkan berkurangnya kepuasan dalam penggunaan dunia virtual. Waktu respon antara pergerakan pengguna dan tampilan pada dunia virtual harus kurang dari 200ms untuk mencegah pengguna merasa pusing.

5) Realistic feedback. Pengaruh atau timbal balik dari aksi yang dilakukan pengguna harus ditampilkan sesegera mungkin dan sesuai dengan ekspektasi pengguna.

6) Faithful viewpoints. Representasi visual dari dunia virtual harus dapat dipetakan ke dalam persepsi pengguna secara normal dan tidak terdapat jeda atau delay ketika pengguna menggerakan kepalanya.

7) Navigation and orientation support. Pengguna harus mengetahui posisi atau keberadaanya di dalam dunia virtual.

8) Clear entry and exit points. Ketika pengguna memasuki atau keluar dari dunia virtual harus diketahui oleh pengguna lain yang berhubungan dengannya.

9) Consistent departures. Prinsip konsistensi menunjukan rancangan dunia virtual yang sesuai dengan penggunannya (konsistensi dalam merepresentasikan objek di dalam dunia virtual).

10) Support for learning. Objek virtual dapat digunakan sebagai sarana atau media untuk belajar.

11) Clear turn-taking. Representasi pengguna atau avatar di dunia virtual dapat berkomunikasi dan berinteraksi satu sama lain secara bergantian.

12) Sense of presence. Persepsi pengguna yang berhubungan dengan keterlibatan dan perasaan, harus membuat pengguna seolah-olah mereka berada di dunia nyata.

Selain itu, tahap ini terdiri dari 3 sub-tahap, yaitu proses audit teknologi, pemetaan masalah ke dalam prinsip heuristik, dan klasifikasi permasalahan berdasarkan fitur desain beserta pemberian usulan pengembangan atau perbaikannya.

Audit Teknologi: Secara umum tahap ini dilakukan untuk mengtehaui apakah kondisi minimum sistem VLE-MuVR terpenuhi berdasarkan kategori tertentu sehingga dapat digunakan oleh pengguna. Kategori tersebut adalah operation of the user's presence, haptic feedback, interactive techniques, dan realistic graphics (Sutcliffe \& Gault, 2004). Audit teknologi dilakukan pada tahap pengenalan sistem. Kemudian pada saat melakukan eksplorasi terhadap sistem, evaluator juga mencatat ada atau tidaknya fitur-fitur serta permasalahan yang berkaitan dengan kategori tersebut.

Pemetaan Masalah ke dalam Prinsip Heuristik: Setelah proses audit teknologi dilakukan, kemudian evaluator akan mencoba sistem sama seperti pengguna secara umum dan mencatat kesulitan atau kendala yang dihadapi. Masalah ini kemudian dipetakan ke dalam 12 prinsip heuristik yang sudah dipaparkan pada Bab 2. Jika suatu permasalahan dapat dikaitkan dengan lebih dari dari satu prinsip heuristik, maka masalah tersebut harus dipetakan ke dalam prinsip yang paling sesuai, kemudian diikuti oleh penjelasan tambahan. Kemudian pada tahap berikutnya setiap prinsip heuristik ditentukan peringkat permasalahannya untuk mengetahui prioritas pengembangan sistem selanjutnya. Terdapat tiga faktor yang dapat mempengaruhi peringkat permasalahan pada setiap prinsip faktor manfaat, yaitu frekuensi, dampak permasalahan, dan daya tahan pengguna. Faktor frekuensi menunjukan seberapa sering permasalahan tersebut terjadi. Faktor dampak permasalahan menunjukan tingkat kesulitan permasalahan tersebut untuk dapat diatasi. Sedangkan faktor daya tahan pengguna berkaitan dengan tingkat ketahanan pengguna dalam 
menghadapi permasalahan tesebut. Untuk menentukan tingkat permasalahan faktor manfaat terhadap suatu sistem, maka digunakan skala penilaian yang ditunjukan pada Tabel 1 (Dix, et al., 2004).

Tabel 1. Skala Penilaian Berdasarkan Peringkat Permasalahan Faktor manfaat

\begin{tabular}{cl}
$\begin{array}{c}\text { Skor } \\
\text { Peringkat }\end{array}$ & \multicolumn{1}{c}{ Keterangan } \\
\hline 0 & $\begin{array}{l}\text { Bukan permasalahan faktor manfaat } \\
\text { Cosmetic: masalah tidak perlu diperbaiki kecuali } \\
\text { terdapat waktu tambahan }\end{array}$ \\
1 & $\begin{array}{l}\text { Minor: masalah dapat diperbaiki tetapi memiliki } \\
\text { prioritas rendah } \\
\text { Major: masalah dapat diperbaiki dan memiliki } \\
\text { prioritas tinggi } \\
\text { Catastrophe: masalah harus diperbaiki sebelum } \\
\text { produk dipublikasikan }\end{array}$ \\
\hline
\end{tabular}

Klasifikasi Permasalahan berdasarkan Fitur Desain: Setelah tahap pemetaan permasalahan ke dalam prinsip heuristik selesai, maka tahap selanjutnya adalah melakukan diagnosis terhadap masalah/kendala yang dihadapi berdasarkan beberapa parameter fitur desain. Parameter yang digunakan untuk mengklasifikasikan fitur desain berdasarkan permasalahannya tersebut adalah sebagai berikut (Sutcliffe \& Gault, 2004):

1) Graphics. Ke dalaman grafis $3 \mathrm{D}$ atau distorsi perspektif dalam melihat lingkungan 3D. Indikator dari parameter ini adalah permasalahan perseptual atau cara pengguna melihat lingkungan $3 \mathrm{D}$.

2) Presence. Pergerakan dan manipulasi keberadaan pengguna, dikategorikan menjadi dua jenis, yaitu perangkat keras yang sedang digunakan oleh pengguna (misalnya glove, joystick, 3D mouse, pointer, dan sebagainya) serta representasi pengguna di dalam VLE. Inidikator dari parameter ini adalah kesulitan dalam melakukan navigasi dan manipulasi.

3) Interaction. Interaksi dengan objek di dalam VLE. Indikator dari parameter ini adalah kegagalan untuk melakukan aksi atau bertindak atau umpan balik yang tidak tepat.

4) Environmental. Beberapa kondisi objek pada lingkungan yang dibuat memiliki dampak yang tidak sesuai. Contohnya suatu objek yang bergerak menembus dinding.

5) Controls. Manipulasi objek atau interaksi dengan objek tertentu, misalnya mengubah posisi suatu objek dan mengubah orientasi sudut pandang.

6) Hardware. Permasalahan perangkat keras, misalnya permasalahan pada smartphone, Google Cardboard, dan head-mounted display (HMD).

Setelah evaluator berhasil mendiagnosa permasalahan yang ada pada setiap parameter fitur desain, tahap berikutnya yang harus dilakukan adalah memberikan peringkat permasalahan yang dapat menyebabkan gangguan dan mengurangi pengalaman pengguna. Kondisi permasalahan yang diperoleh dari evaluator dikategorikan berdasarkan 4 tingkat (Sutcliffe \& Gault, 2004), yaitu sebagai berikut:

1) Severe. Masalah yang ditemui menyebabkan pengguna tidak dapat melakukan aktivitasnya di VLE. Dengan kata lain, perintah yang diberikan pada VLE tidak dapat diselesaikan.

2) Annoying. Masalah yang ditemui akan mengganggu pengguna untuk melakukan aktivitasnya di VLE. Walaupun demikian sebagaian besar akan beradaptasi untuk mengatasi permasalahan yang ada, namun biasanya untuk mengatasi permasalahan ini membutuhkan waktu yang relatif lama.

3) Distracting. Permasalahan akan mengganggu aktivitas pengguna di dalam VLE, tetapi sebagian besar pengguna dapat mengatasinya dengan waktu yang relatif singkat dengan adanya penjelasan dan bantuan atau petunjuk.

4) Inconvenient. Permasalahan akan mengganggu aktivitas pengguna, namun sebagian besar pengguna dapat mengatasinya tanpa bantuan.

Setelah proses pemberian peringkat permasalahan selesai ditentukan, kemudian evaluator memberikan rekomendasi atau usulan perbaikan desain untuk setiap parameter fitur desain

\subsection{Analisis Cybersickness}

Cybersickness merupakan gejala yang biasanya ditandai dengan pusing, mual, atau mata lelah (Paulus, et al., 2016). Gejala ini biasanya dipengaruhi oleh berbagai faktor, beberapa diantaranya adalah usia, riwayat penyakit, jenis kelamin, maupun posisi pengguna ketika menggunakan perangkat VR (LaViola Jr, 2000). Selain itu permasalahan dari sisi teknis juga merupakan salah satu faktor penyebab Cybersickness. Masalah teknis tersebut dapat berupa alat tracking yang tidak sinkron dengan posisi anggota tubuh pengguna (misalnya head tracking) ataupun disebabkan karena adanya lag yang menyebabkan adanya waktu jeda pada setiap pergantian frame pada layar. Permasalahan terkait Cybersickness lainnya juga dapat disebabkan oleh flicker atau kedipan yang menimbulkan perubahan kecerahan pada layar layar. Pengaruh flicker dapat dicegah dengan meningkatkan refresh rate layar (minimal $30 \mathrm{~Hz}$ ) (LaViola Jr, 2000).

Investigasi pengaruh penggunaan sistem 3DMuVLR terhadap gejala Cybersickness dilakukan dengan cara menguji sistem dengan menggunakan $V R$ Box. Ketika evaluator menunjukan gejala cybersickness maka pengamat akan mencatat durasi penggunaan perangkat VR dan faktor pemicunya mulai dari pemasangan perangkat di masing-masing evaluator. 


\section{HASIL}

Penelitian telah dilakukan untuk menguji aspek faktor manfaat dari sistem VR dengan jenis semiimmersive, yaitu 3D-MuVLR. Sistem ini akan digunakan sebagai tempat untuk melakukan kegiatan belajar mengajar di luar kelas yang sebenarnya. Sesuai yang tertera pada Gambar 3, sistem ini diakses menggunakan perangkat komputer yang kemudian divisualisasikan ke pengguna menggunakan kacamata VR. Pengguna direpresentasikan sebagai avatar yang dapat menggunakan objek-objek virtual untuk melaksanakan kegiatan pembelajaran. Evaluasi dilakukan oleh 3 orang evaluator yang mendalami konsep evaluasi sistem dan belum pernah menggunakan sistem 3D-MuVLR.

\subsection{Audit Teknologi}

Berdasarkan proses investigasi terhadap sistem, berikut ini merupakan hasil audit teknologi yang diperoleh.

Operation of the user's presence: Setiap pengguna di dalam 3D-MuVLR direpresentasikan sebagai avatar sehingga pergerakan fisiknya dapat diamati. Tampilan fisik setiap avatar dapat diubah atau disesuaikan (kustomisasi) dengan keinginan masingmasing penggunanya. Pengguna dapat berinteraksi dengan berbagai objek dengan memanfaatkan mouse dan keyboard. Pengguna dapat berinteraksi dengan berbagai objek dengan menggunakan tombol klik kanan maupun klik kiri pada mouse. Klik kanan berfungsi untuk menampilkan sejumlah menu pada suatu objek, sedangkan klik kiri berfungsi sebagai tombol aksi (memilih) terhadap suatu menu. Pengguna juga dapat menggunakan keyboard untuk menggerakan avatar (berjalan) dan menulis pesan ke pengguna lain. Selain itu pengguna juga dapat mengubah mode tampilan baik dalam sudut pandang first person maupun third person dengan cara melakukan scroll pada mouse yang digunakan. Ketika dalam mode first person, keberadaan pengguna ditandai oleh pointer yang berfungsi sebagai petunjuk atau patokan sudut pandang, sehingga gerakan kepala pengguna akan langsung mempengaruhi kamera atau sudut pandang avatar. Ketika dalam mode third person, pengguna harus meng-klik tubuh avatar dan menahannya sambil menggerakan kepala, sehingga sudut pandang avatar juga ikut berubah. Walaupun demikian akan lebih baik jika walaupun dalam mode third person, gerakan kepala sesuai dengan sudut pandang avatar tanpa menggunakan mouse.

Haptic feedback: Sistem ini memiliki berbagai menu, tombol, dan objek lain yang dapat digunakan. Ketika pointer diarahkan (hover) ke menu atau tombol yang aktif (dapat digunakan), maka tombol tersebut akan berubah warna menjadi lebih terang dan satu detik kemudian akan muncul deskripsi dari menu atau tombol yang dimaksud. Berbeda menu dan tombol, jika pointer diarahkan ke objek yang dapat digunakan maka pointer akan berubah menjadi gambar tangan yang. Contohnya ketika pointer diarahkan ke objek berupa kursi, maka pointer langsung berubah menjadi gambar tangan dilengkapi dengan gambar kursi yang mengindikasikan bahwa objek tersebut dapat digunakan untuk duduk.

Interactive techniques: $\mathrm{Di}$ dalam 3D-MuVLR pengguna dibagi menjadi dua kategori utama, yaitu administrator dan pengguna biasa. Administrator dapat menambahkan, menghapus, mengubah, maupun memindahkan semua objek-objek yang ada, sedangkan pengguna biasa hanya dapat menggunakan objek tertentu sesuai fungsinya saja. Ketika administrator melakukan klik kanan terhadap suatu objek, maka akan muncul banyak pilihan yang dapat digunakan untuk memanipulasi objek tersebut. Namun beberapa pilihan tidak aktif (tidak dapat digunakan) oleh pengguna biasa. Beberapa objek yang pada umumnya digunakan pada sistem ini adalah registration enrollment booth, kursi biasa, kursi kuis, dan Presenter. Ketika pengguna biasa mengk-klik registration enrollment booth, maka akan muncul pop-up windows yang menyambungkan sistem dengan browser sehingga pengguna menjadi peserta belajar di suatu course . Kursi biasa digunakan sebagai tempat duduk, sedangkan kursi kuis digunakan untuk melakukan ujian/kuis. Ketika pengguna mengklik kursi-kursi tersebut, maka otomatis avatar akan langsung duduk di kursi yang dituju. Lebih dari itu, setiap soal yang dijawab dengan benar oleh pengguna, maka kursi kuis akan bertambah ketinggiannya (melayang) dan akan turun ketika soal yang dijawab salah. Presenter digunakan sebagai media untuk menampilkan sumber atau bahan ajar baik dalam bentuk gambar (slide), audio, maupun video pembelajaran. Presenter untuk gambar memiliki tombol previous dan next untuk mengganti gambar (slide) di dalamnya. Sedangkan Presenter untuk audio/video dilengkapi dengan tombol-tombol sebagai pemutar dan pengendali konten multimedia, misalnya play/pause, previous, next, dan sebagainya.

Realistic graphics: Representasi visual dalam sistem ini bergantung pada pengaturan grafik yang dapat diubah mulai dari tingkat low, medium, dan high. Terlepas dari spesifikasi komputer yang digunakan, secara umum lingkungan virtual di dalam 3DMuVLR memiliki visualisasi objek yang cukup detail. Walaupun demikian terdapat beberapa objek yang tidak terlalu detail dibandingkan dengan objek lainnya. Objek-objek tersebut adalah peta, air laut, dan tumbuhan air yang berada di dalam kolam.

\subsection{Pemetaan Masalah ke Prinsip Heuristik}

Tabel 2 menunjukan hasil pemetaan permasalahan yang diperoleh dari tahap audit teknologi ke dalam 12 aturan heuristik beserta peringkat permasalahannya. Berdasarkan hasil 
evaluasi, secara umum 3D-MuVR dapat dikatakan hanya memiliki sedikit permasalahan. Hanya dua dari total 12 prinsip heuristik yang memiliki permasalahan peringkat 3 atau tingkatan major dan satu prinsip berada pada peringkat minor. Sisanya berada pada peringkat 0 atau 1. Prinsip yang berada pada kategori mayor adalah clear entry and exit points dan support for learning. Sedangkan prinsip navigation and orientation support berada pada peringkat minor.

Beberapa permasalahan yang berada pada peringkat 1 diantaranya adalah seluruh lingkungan virtual dikelilingi lautan, arah gerak kibaran bendera yang tidak sama, dan ada sedikit bagian tubuh yang dapat menembus objek solid seperti yang ditunjukan pada Gambar 5, Gambar 6, dan Gambar 7.

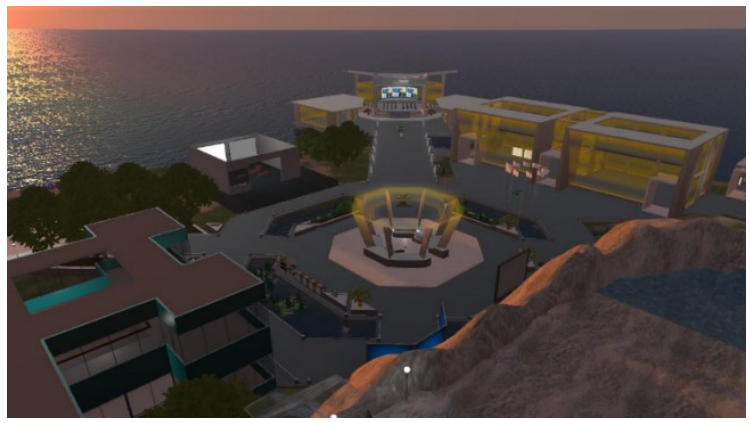

Gambar 5. Lautan di sekitar 3D-MuVLR

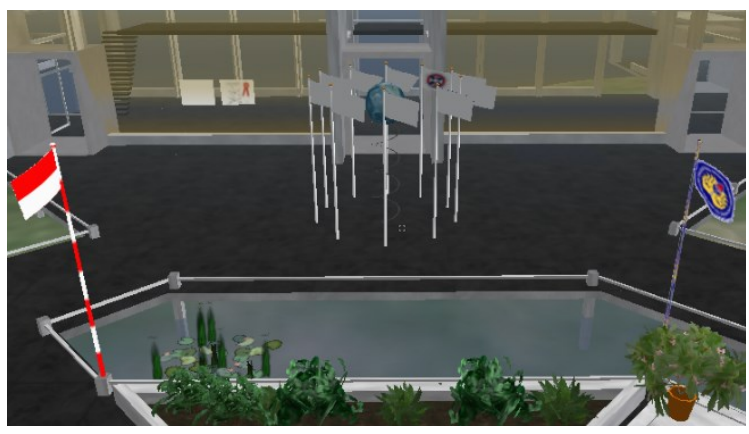

Gambar 6. Perbedaan Arah Kibaran Bendera

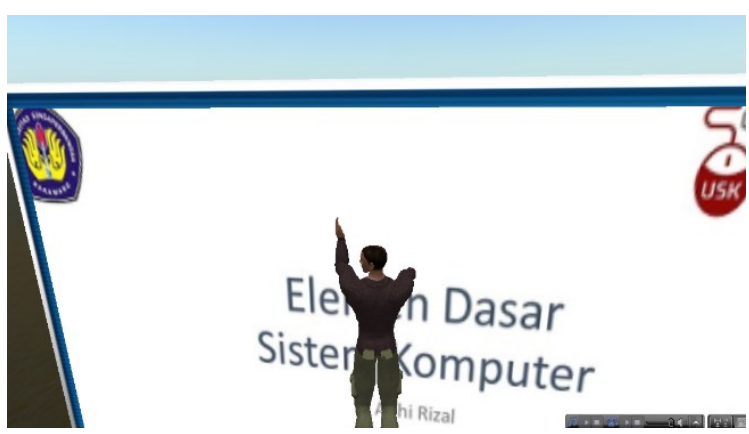

Gambar 7. Bagian Tubuh Menembus Presenter

Permasalahan prinsip clear entry and exit points disebabkan karena tidak ada informasi mengenai di mana posisi avatar ketika login ke dalam sistem sehingga pengguna akan kebingunan di mana posisinya saat ini. Di dalam sistem ini pengguna memiliki dua pilihan, apakah posisi avatar pada saat login adalah posisi terakhir ketika logout atau kembali ke posisi awal (di pusat lingkungan virtual).

Permasalahan pada prinsip support for learning disebabkan karena tidak adanya petunjuk mengenai bagaimana cara melaksanakan kegiatan pembelajaran dengan memanfaatkan objek-objek yang tersedia, misalnya informasi prosedur registrasi ke course tertentu, menggunakan Presenter, browser, dan melaksanakan ujian menggunakan objek kursi kuis.

\subsection{Klasifikasi Permasalahan berdasarkan Fitur Desain}

Setelah tahap pemetaan permasalahan ke dalam prinsip heuristik selesai, maka evaluator berdiskusi kembali untuk mengklasifikasikan permasalahan berdasarkan fitur desain. Hasil dari proses ini ditunjukan pada

Tabel 3. Dari enam komponen fitur desain, hanya dua fitur yang termasuk ke dalam kategori distracting, yaitu presence dan interaction.

Pada fitur presence teridentifikasi bahwa ketika pengguna melakukan login ke dalam sistem, proses render fisik avatar dirinya lambat. Tidak semua komponen fisik avatar (terutama pakaian yang dikenakan) langsung muncul walaupun sistem sudah berjalan selama beberapa menit. Untuk mengatasi hal ini maka pengguna harus melakukan klik kanan terhadap avatarnya kemudian memilih menu appearance agar semua komponen avatar langsung ter-load, walaupun tidak bertujuan untuk mengubahnya. Pada fitur interaction, teridentifikasi bahwa bahwa tidak semua pengguna mengetahui apa yang akan dan dapat dilakukan terhadap suatu objek, terutama untuk melaksanakan kegiatan pembelajaran. Sehingga solusi yang direkomendasikan adalah menyediakan papan informasi di dalam sistem yang berisi prosedur baik untuk mengakses objek yang dibutuhkan untuk melaksanakan kegiatan pembelajaran maupun objek lain yang dapat digunakan secara umum.

\subsection{Analisis Gejala Cybersickness}

Hasil uji coba sistem untuk menginvestigasi gerakan atau posisi pemicu cybersickness dapat dilihat pada Tabel 4. Evaluator mengidentifikasi bahwa pergerakan pointer atau sudut pandang di dalam sistem terlalu cepat dan sedikit berguncang. Hal ini disebabkan karena sensor gyroscope pada smartphone terlalu sensitif sehingga dibutuhkan proses kalibrasi. 
Tabel 2. Pemetaan dan Peringkat Permasalahan ke dalam 12 Prinsip Heuristik

\begin{tabular}{|c|c|c|c|}
\hline No & Heuristik & Peringkat & Masalah \\
\hline 1 & Natural engagement & 1 & $\begin{array}{l}\text { - Seluruh lingkungan virtual dikelilingi lautan } \\
\text { - Arah gerak kibaran bendera yang dipengaruhi angin tidak sama } \\
\text { - Ada sedikit bagian tubuh yang dapat menembus objek solid (misalnya bagian kepala yang } \\
\text { dapat menembus dinding) } \\
\text { - Wilayah eksplorasi avatar terbatas karena adanya batasan region (batas wilayah) } \\
\text { - Tidak ada animasi ketika avatar duduk }\end{array}$ \\
\hline 2 & $\begin{array}{l}\text { Compatibility with the } \\
\text { user's task and domain }\end{array}$ & 1 & $\begin{array}{l}\text { - Avatar memiliki fitur terbang } \\
\text { - Tidak ada tombol logout tapi bisa melalui tombol exit aplikasi }\end{array}$ \\
\hline 3 & $\begin{array}{l}\text { Natural expression of } \\
\text { action }\end{array}$ & 0 & $\begin{array}{l}\text { Tidak ada permasalahan karena pengguna dapat berinteraksi dengan bebas dengan objek- } \\
\text { objek yang ada seuai dengan fungsinya. Selain itu pengguna juga dapat mengekspresikan } \\
\text { emosinya dengan menggerakan avatarnya berdasarkan jenis gerakan yang ada (beberapa } \\
\text { motion dapat ditambahkan sebelumnya) }\end{array}$ \\
\hline 4 & $\begin{array}{l}\text { Close coordination of } \\
\text { action and } \\
\text { representation }\end{array}$ & 1 & Terdapat jeda ketika administrator menambahkan suatu objek yang ukurannya cukup besar \\
\hline 5 & Realistic feedback & 0 & $\begin{array}{l}\text { Tidak ada permasalahan karena semua objek, menu, dan tombol akan menghasilkan } \\
\text { feedback ketika digunakan, misalnya menu atau tombol yang berubah warna ketika disorot } \\
\text { atau dipilih dan objek yang berubah secara fisik ketika digunakan }\end{array}$ \\
\hline 6 & Faithful viewpoints & 1 & $\begin{array}{l}\text { Secara umum baik, walaupun ada sedikit lag atau delay pada visualisasi ketika pengguna } \\
\text { menggerakan kepala terlalu cepat }\end{array}$ \\
\hline 7 & $\begin{array}{l}\text { Navigation and } \\
\text { orientation support }\end{array}$ & 2 & $\begin{array}{l}\text { - Tidak ada petunjuk mengenai cara untuk beralih dari sudut pandang first }{ }^{t} \text { person } \text { ke } \text { third } \\
\text { person ataupun sebaliknya } \\
\text { - Terkadang terjadi disorientasi sudut pandang tampilan yang disebabkan sensor gyroscope } \\
\text { pada perangkat smartphone tertentu }\end{array}$ \\
\hline 8 & $\begin{array}{l}\text { Clear entry and exit } \\
\text { points }\end{array}$ & 3 & $\begin{array}{l}\text { Tidak ada informasi mengenai di posisi mana nantinya avatar muncul sesaat setelah login } \\
\text { dan tidak ada tata cara yang benar mengenai bagaimana keluar dari sistem }\end{array}$ \\
\hline 9 & Consistent departures & 0 & $\begin{array}{l}\text { Semua teks, objek, menu, dan tombol memiliki bentuk, tampilan, dan fungsioniltas yang } \\
\text { proporsional dan sama atau konsisten }\end{array}$ \\
\hline 10 & Support for learning & 3 & $\begin{array}{l}\text { Tidak ada petunjuk mengenai bagaimana cara registrasi ke course tertentu, menggunakan } \\
\text { Presenter, browser, dan melaksanakan ujian menggunakan kursi kuis }\end{array}$ \\
\hline 11 & Clear turn-taking & 0 & $\begin{array}{l}\text { - Pertukaran pesan antar pengguna melalui chat box dapat berjalan dengan baik secara } \\
\text { bersamaan. } \\
\text { - Voice chat dapat digunakan dengan baik }\end{array}$ \\
\hline 12 & Sense of presence & 1 & $\begin{array}{l}\text { Proses render tampilan avatar, objek, dan lingkungan terlihat lambat, terutama ketika } \\
\text { avatar pertama kali masuk ke dalam sistem }\end{array}$ \\
\hline
\end{tabular}

Tabel 3. Klasifikasi Permasalahan Berdasarkan Fitur Desain

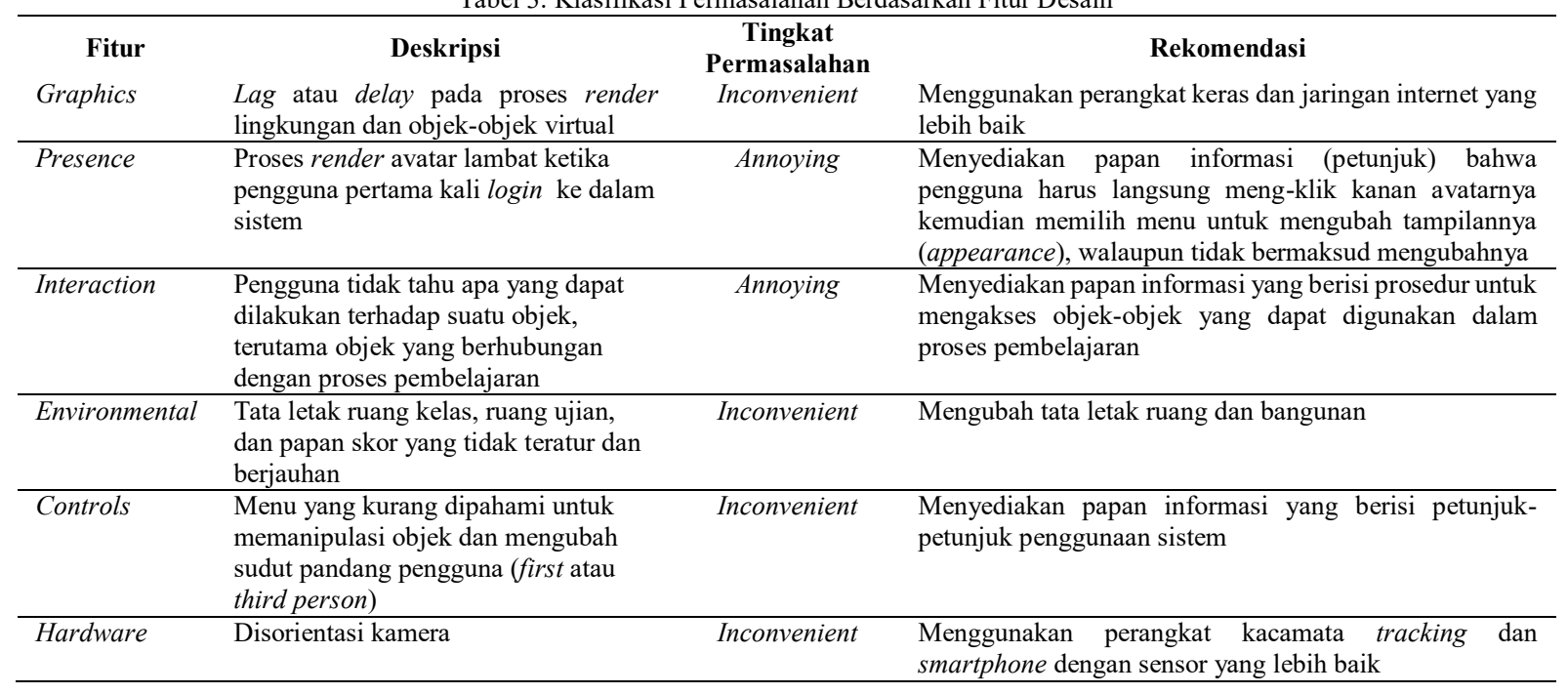

Tabel 4. Gerakan atau Posisi Pemicu Cybersickness

\begin{tabular}{ccl}
\hline Evaluator & $\begin{array}{c}\text { Waktu Penggunaan } \\
\text { (menit) }\end{array}$ & \multicolumn{1}{c}{ Gerakan/Posisi Pemicu Cybersickness } \\
\hline 1 & 5 & Perubahan posisi kepala dari melihat ke atas kemudian ke bawah atau kanan ke kiri dengan cepat \\
2 & 8 & Posisi kepala mengahadap ke atas kemudian berubah dengan cepat menjadi posisi menunduk \\
3 & 8 & Posisi kepala menghadap ke bawah dan menggelengkan kepala \\
\hline
\end{tabular}

Berdasarkan Tabel 4 ditemukan bahwa semua evaluator mulai merasakan pusing walaupun durasi penggunaan belum mencapai sepuluh menit. Walaupun demikian, selain berasal dari sisi teknis seperti yang telah dipaparkan pada sub-bab sebelumnya, faktor pemicu cybersickness ini juga dapat disebabkan oleh usia, jenis kelamin, riwayat penyakit, atau posisi pengguna ketika menggunakan 
perangkat VR. Gerakan cepat perubahan posisi kepala dengan cepat merupakan faktor yang paling berpengaruh terhadap muculnya gejala cybersickness. Selain itu ditemukan juga bahwa jenis lensa, jarak antar lensa dan jarak lensa dengan mata, ukuran lensa, serta faktor kenyamanan keseluruhan kacamata juga berpengaruh terhadap munculnya gejala cybersickness.

\section{KESIMPULAN}

Secara umum 3D-MuVLR merupakan sistem pembelajaran 3 dimensi yang divisualisasikan menggunakan VR dengan konsep semi-immersive. Sistem ini dapat dievaluasi menggunakan konsep evaluasi heuristik yang terdiri dari 12 prinsip. Evaluasi ini berhasil mengidentifikasi beberapa permasalahan beserta solusi terkait aspek faktor manfaat dan keberadaan pengguna di dalam dunia virtual.

Berdasarkan hasil evaluasi terdapat dua prinsip heuristik yang memiliki permasalahan dengan peringkat 3 (major), yaitu clear entry and exit points dan support for learning, sedangkan sisanya berada pada peringkat 0 atau 1. Permasalahan major tersebut disebabkan karena tidak adanya informasi mengenai posisi avatar ketika login (di posisi default atau posisi terakhir ketika pengguna logout), tidak ada petunjuk untuk keluar dari sistem, dan tidak adanya petunjuk untuk melaksanakan proses pembelajaran dengan menggunakan objek-objek yang ada. Dengan adanya temuan ini, maka solusi dari permasalahan ini adalah dengan menyediakan papan informasi di dalam sistem.

Selain dari aspek faktor manfaat dan keberadaan pengguna, permasalahan lain yang berkaitan dengan cybersickness juga berhasil teridentifikasi. Dalam waktu kurang dari sepuluh menit, evaluator menyatakan bahwa mereka mulai merasakan gejala pusing. Berdasarkan hal ini ditemukan bahwa terdapat beberapa faktor yang dapat mempengaruhi munculnya gejala cybersickness ketika menggunakan sistem. Faktor-faktor yang paling berpengaruh diantaranya adalah gerakan cepat ketika merubah posisi kepala dan sensitifitas sensor gyroscope pada smartphone yang digunakan. Untuk meminimalisir gejala ini pengguna dapat melakukan konfigurasi lensa pada perangkat VR agar sesuai dengan posisi mata dan lebar layar ponsel serta mengatur kualitas grafik dan menyesuaikan resolusi pada aplikasi trinus PC maupun ponsel. Selain itu pengguna juga dapat beristirahat dengan cara melepaskan perangkat VRnya setiap \pm 10 menit.

\section{DAFTAR PUSTAKA}

ABUlRuB, A. G. A. A. N. \& WILliamS, M. A., 2011. Virtual reality in engineering education: The future of creative learning. Amman, IEEE, pp. 751-757.
ACHIRUZAMAN, M. \& ROSMANSYAH, Y., 2016. A framework for $3 \mathrm{D}$ virtual game using MOODLE, SLOODLE and Open Simulator: Case Study: Training of house building data collecting by National Statistical Office (NSO), Government Agency, BPS - Statistics Indonesia. Bandung, IEEE, pp. 1-6.

AK, O. \& KUTLU, B., 2015. Comparing 2D and 3D game-based learning environments in terms of learning gains and student perceptions. British Journal of Educational Technology, 48(1), pp. 129-144.

BARNUM, C. M., 2002. Usability Testing and Research. New York: Pearson Education.

BAUS, O. \& BOUCHARD, S., 2014. Moving from virtual reality exposure-based therapy to augmented reality exposure-based therapy: a review. Frontiers in human neuroscience, 8(112).

CARTELLI, A., 2009. The Implementation of Practices with ICT as a New TeachingLearning Paradigm. Cassino: PA: IGI Global.

ÇAVAŞ, B., ÇAVAŞ, P. H. \& CAN, B. T., 2004. Virtual reality in education. Turkish Online Journal of Educational Technology.

CHAGUÉ, S. \& CHARBONNIER, C., 2016. Real virtuality: a multi-user immersive platform connecting real and virtual worlds. Laval, s.n.

CHAU, M. ET AL., 2013. Using 3D virtual environments to facilitate students in constructivist learning. Decision Support Systems 56 (2013), pp. 115-121.

COSTELlO, P., 1997. Health and Safety Issues associated with Virtual Reality - A Review of Current Literature, Loughborough: Advanced VR Research Centre Dept. of Human Sciences Loughborough University.

DAVIS, S., NESBITT, K. \& NALIVAIKO, E., 2015. Comparing the onset of cybersickness using the Oculus Rift and two virtual roller coasters. Sydney, CRPIT.

DE BRA, P. ET AL., 2010. GRAPPLE: Personalization and Adaptation in Learning Management Systems. Berlin, Springer, Berlin, Heidelberg, pp. 133-160.

DIX, A., FINLAY, J., ABOWD, G. D. \& BEALE, R., 2004. Human-Computer Interaction. London: Pearson Education.

DOMINGO, J. R. \& BADLEY, E. G., 2018. Education Student Perceptions of Virtual Reality as a Learning Tool. Journal of Educational Technology Systems, pp. 329342.

EWAIS, A. \& DE TROYER, O., 2013. Usability Evaluation of an Adaptive 3D Virtual Learning Environment. International Journal 
of Virtual and Personal Learning Environments, 4(1), pp. 16-31.

EWAIS, A. \& DE TROYER, O., 2014. Authoring Adaptive 3D Virtual Learning Environments. International Journal of Virtual and Personal Learning Environments, pp. 1-19.

KARAMAN, M. K. \& ÖZEN, S. O., 2016. A Survey of Students' Experiences on Collaborative Virtual Learning Activities Based on FiveStage Model. Journal of Educational Technology \& Society, pp. 247-259.

LAVIOLA JR, J. J., 2000. A Discussion of Cybersickness in Virtual Environments. s.1., ACM, pp. 47-55.

LIVINGSTONE, D. \& KEMP, J., 2008. Integrating Web-Based and 3D Learning Environments: Second Life Meets Moodle. CEPIS UPGRADE: European Journal for the Informatics Professional, pp. 8-14.

MARTÍN-GUTIÉRREZ, J., MORA, C. E., AÑORBE-DÍAZ, B. \& GONZÁLEZMARRERO, A., 2017. Virtual Technologies Trends in Education. EURASIA Journal of Mathematics Science and Technology Education, pp. 469-486.

MATHEW, S., 2014. Importance of Virtual Reality in Current World. International Journal of Computer Science and Mobile Computing , 3(3), pp. 894-899.

MOORE, P., 1995. Learning and teaching in virtual worlds: Implications of virtual reality for education. Australian Jounal of Educational Technology, pp. 91-102.

NIELSEN, J., 1993. Usability Engineering. London: Academic Press.

PAULUS, E., SURYANI, M. \& FARABI, R., 2016. Evaluasi Usabilitas pada Aplikasi Virtual Reality untuk Pendidikan: Studi Kasus BIOTALAUTVR. Yogyakarta, STMIK AKAKOM , pp. 107-113.

PICCOLI, G., AHMAD, R. \& IVES, B., 2001. WebBased Virtual Learning Environments: A Research Framework and a Preliminary Assessment of Effectiveness in Basic IT Skills Training. MIS Quarterly, pp. 401-426.

RAMAPRABHA, T. \& SATHIK, M. M., 2012. The Efficiency Enhancement in Non Immersive Virtual Reality System by Haptic Devices. International Journal of Advanced Research in Computer Science and Software Engineering, 2(3), pp. 113-117.

REISOĞLU, İ. ET AL., 2017. 3D virtual learning environments in education: a meta-review. Asia Pacific Education Review , pp. 81-100.

RIZAL, A., ADAM, R. I. \& SUSILAWATI, 2018. Pengembangan Laboratorium Virtual Fisika Osilasi. Jurnal Online Informatika (JOIN), 3(1), pp. 55-60.
RIZAL, A., ADAM, R. I. \& SUSILAWATI, 2018. Sistem Kelas Virtual dan Pengelolaan Pembelajaran Berbasis 3-Dimensional Virtual World. Jurnal Edukasi dan Penelitian Informatika, pp. 132-140.

SIMONICS, I., 2013. Changing of multimedia elements in eLearning development. s.l., IEEE.

SUTCLIFFE, A. \& GAULT, B., 2004. Heuristic evaluation of virtual reality applications. Elsevier Interacting with computers, pp. 831-849.

THAMARANA, S., 2016. Role of E-learning and Virtual Learning Environment in English language learning. Andhra Pradesh,ELT@I Tirupati Chapter.

TORUN, F. \& TEKEDERE, H., 2015. The Usability Analysis of An E-Learning Environment. Turkish Online Journal of Distance Education, pp. 50-66.

VELEV, D. \& ZLATEVA, P., 2017. Virtual Reality Challenges in Education and Training. International Journal of Learning and Teaching, 3(1), pp. 33-37.

VERTESI, A. ET AL., 2018. Usability Evaluation of A Virtual Learning Environment: A University Case Study. Budapest, s.n.

WILSON, B., 1997. Constructivist Learning Environments: Case Studies in Instructional Design. IEEE TRANSACTION ON PROFESSIONAL COMMUNICATION, pp. 310-312.

YILDIRIM, G., ELBAN, M. \& YILDIRIM, S., 2018. Analysis of Use of Virtual Reality Technologies in Histori Education: A Case Study. Asian Journal of Education and Training, pp. 62-69.

ZHAO, D., 2018. CoVR: Cloud-Based Multiuser Virtual Reality Headset System for Project Communication of Remote Users. Journal of Construction Engineering and Management, 144(2). 